\title{
ANTIFORMALISMO Y ENJUICIAMIENTO EFECTIVO EN EL SISTEMA DE LA JUSTICIA CONSTITUCIONAL (I) *
}

\author{
POR \\ LORENZO MARTIN-RETORTHLLO BAQUER \\ Catedrático de Derecho Administrativo \\ Universidad de Zaragoza
}

\begin{abstract}
SUMARIO
I. INTRODUCCIÓN: EL RIGORISMO FORMALISTA TAN ARRAIGADO EN EL SISTEMA JURISDICCIONAL ESPAÑOL. EN ESPECIAL, EL FRACASO DE LA INTENCIÓN SUPERADORA DE LA LEY DE LO CONTENCIOSO-ADMINISTRATIVO.-II. LA RESPUESTA NORMATTVA EN EL ÁMBITO DE LA JUSTICIA CONSTITUCIONAL.-III. ANÁLISIS DE LA PRIMERA JURISPRUDENCIA DEL TRIBUNAL CONSTITUCIONAL: EL IMPULSO ANTIFORMALISTA COMO CRITERIO.
\end{abstract}

\section{I}

1. Al hilo del centenario de la LEC $^{1}-1881-$ y de la LECrim -1882-, de $\tan$ distinto alcance en sus puntos de partida, como ha sido bien notado ${ }^{2}$, Revista.

* La segunda parte de este artículo se publicará en el número siguiente de nuestra

${ }^{1}$ Abreviaturas utilizadas:

BJC

Boletín de Jurisprudencia Constitucional.

BOCG ................... Boletín Oficial de las Cortes Generales.

BOE ...................... Boletin Oficial del Estado.

CE …................... Constitución española de 1978.

FJ ....................... Fundamento Jurídico.

IEAL ..................... Instituto de Estudios de Administración Local.

LEC

Ley de Enjuiciamiento Civil.

LECrim ................... Ley de Enjuiciamiento Criminal.

LJ ..................... Ley Reguladora de la Jurisdicción contencioso-administrativa.

LOPJ …................ Ley Orgánica del Poder Judicial.

LOTC ................... Ley Orgánica del Tribunal Constitucional.

LPA ..................... Ley de Procedimiento Administrativo.

RAP ....................... Revista de Administración Pública.

REDA ................... Revista Española de Derecho Administrativo.

TC ...................... Tribunal Constitucional.

TS ........................ Tribunal Supremo.

${ }^{2}$ Me remito al sugestivo librito de Juan Montero Aroca, Análisis crítico de la Ley de Enjuiciamiento Civil en su centenario, Cuadernos Cívitas, Madrid, 1980, págs. 19 y sigs.

Revista de Derecho Político

Núm. 16. Invierno 1982-1983 
transcurridos apenas los primeros veinticinco años de vigencia de la $\mathrm{LJ}$, y presto ya - y bueno es festejarlo- el cuarto aniversario de la Constitución, al ser invitado a participar en este número monográfico sobre la justicia constitucional, si había un ramillete de temas apetecibles para desarrollar, no me ha costado, en cambio, decidirme por el que va a ser objeto de mis reflexiones, el del antiformalismo que es dable observar, generosamente, en las - ya no escasas, pero todavía iniciales- decisiones del Tribunal Constitucional. He elegido así, con toda intención, un tema menor, un aspecto minucioso, que con frecuencia no consideran los que juegan con las pompas de jabón de las grandes palabras, pero que resulta decisivo. Al menos esa convicción espero llevar al ánimo del lector.

No será preciso insistir mucho acerca del ritualismo que atenaza en la práctica la administración de la justicia. No sólo el desfase de los procedimientos con las necesidades de hoy influye; es cierto, hay otras muchas causas que se han ido acumulando como estratos; así, ya en otro ámbito, las enormes carencias materiales -de edificios, de instalación auxiliar y dotaciones-, pero las de personal sobre todo, que tanto dificultan su tarea a los hombres de la justicia $^{3}$. No pocas son, en efecto, las facetas que contribuyen a hacer difícil y menesteroso el paso de la carroza de la justicia ${ }^{4}$. Ahora sólo quiero fijarme en

${ }^{3}$ Por fortuna se están produciendo una serie de estudios, auspiciados o fomentados, incluso en ocasiones por el propio Consejo General del Poder Judicial, que, ahora que pueden decirse las verdades, sorprenden con frecuencia por la crudeza de sus conclusiones, pero que son el primer paso indispensable para acometer las reformas necesarias. Tengo presente, así, como muestra, el «Informe que presenta la Comisión sobre la reforma de la administración de Justicia a la consideración de la Junta General del Real e Ilustre Colegio de Abogados de Zaragoza", separata del Boletín General de los Colegios de Abogados de Aragón, 1 de febrero de 1982, cuyas constataciones, cuando se asumen desde la perspectiva del funcionamiento de los aparatos del Estado, causan sonrojo, por decirlo en una palabra. Así comienza en las conclusiones, la que se refiere a los medios materiales y procesales: «Estamos de acuerdo con el Consejo General del Poder Judicial en que la situación actual es insostenible...» (pág. 49). Etcétera.

Sin insistir ahora sobre el tema, apremiante sin duda, y que merece toda clase de esfuerzos, sólo dejaré constancia de la pregunta elemental que tal constatación provoca: ¿Cómo es posible llegar a alcanzar esta situación? ¿Cómo explicarán los responsables del anterior período tan palmaria dejadez?

Desde otra perspectiva, recordaré algo sobre lo que hace poco he insistido: cómo hasta la promulgación de la Constitución de 1978 , con su título VI, que quiere instaurar un auténtico Poder Judicial, en el panorama institucional español lo judicial ofrecía una neta situación de subordinación ante la preeminencia de otros poderes del Estado. Me remito, así, a mi trabajo La Ley de Conflictos Jurisdiccionales tras la entrada en vigor de la Constitución, ponencia sostenida, en mayo de 1982, en las Jornadas sobre el Poder Judicial, organizadas por la Dirección General de lo Contencioso del Estado, y de próxima publicación.

${ }^{4}$ Recordaré que en el atrayente librito de Bernard Schwartz, Los diez mejores jueces de la bistoria norteamericana, traducción de Entique Alonso, Cuadernos Cívitas, Madrid, 1980, págs. 79 y sigs., uno de los méritos descollantes que atribuye al juez Arthut T. Vanderbilt para incluirle en tan relevante olimpo es el de haber combatido, eficazmente, la ineficacia judicial. Así dirá de él: «'Había marineros y caballeros en la Armada de Carlos II. Pero los caballeros no eran marineros ni los marineros caballeros'. Lo mismo puede decirse de los Tribunales americanos: hay jueces y hay administradores. Pero los jueces no son administradores ni los administradores jueces. Tenemos, sin embargo, una excepción: Arthur T. Vanderbilt, presidente del Tribunal Supremo de Nueva Jersey; el más eficaz administrador judicial de la historia de los Estados Unidos. Sus reformas en la Administración de 
ésta del ritualismo: esa maraña de trámites, formalidades, ritos, exigencias y solemnidades, tan alejados con frecuencia del momento y la teleología que les. dio origen, tan carentes, por tanto, como norma, de su originaria funcionalidad. Acaso en su momento tuvieran algún sentido. A lo que parece, hoy nohacen que sea mejor la justicia. Al contrario, se pensaría que la dificultan, bien porque la retrasan, bien porque la alejan o la hacen más gravosa, bien porque la encarecen o la apartan de importantes capas de ciudadanos que con frecuencia son los que más necesitan de ella. Empero, tan arraigados parecen tales obstáculos, son de tal manera rutina asimilada, que se diría forman parte del paisaje social y apenas desentonan. No se trata ahora de describir, insisto, sino tan sólo de tomar nota de algo elemental y de común conocimiento.

2. Vaya por delante, con todo, una advertencia muy clara: no se pretende hacer ascos a una regulación, aun pormenorizada, que introduzca requisitos: de forma, de tiempo, fórmulas precisas incluso. Una ordenación clara de las. exigencias - presidida siempre por el contraste afinado y permanente de la funcionalidad de cada una de ellas, la toma en consideración constante de la finalidad a la que están ordenadas - puede ser la mejor garantía para el adecuado funcionamiento de la justicia. Valores como el de la igualdad o la seguridad, tan auspiciables, hallan el mejor acomodo a través de unas exigencias procesales firmes e inequívocas. Nada más lejos de mi ánimo que negar, por tanto, su valor a lo que habitualmente llamamos exigencias formales. Es el pan nuestro de cada día, el ABC de cualquier modelo jurisdiccional. De siempre se ha dicho - por traer un ejemplo próximo, pero de campo ajeno- que un procedimiento administrativo claro y eficiente cubre como una de sus funciones más destacadas la de garantía de los propios ciudadanos. Las exigencias formales contenidas en su ámbito y en su funcionalidad -estrictamente vigiladas, sí, para que no desborden- están llamadas a ser liberadoras. En ocasiones como ésta se suelen repetir las conocidas palabras de Montesquieu: «Les formalités de la justice sont nécessaires à la liberté» ${ }^{5}$.

Está claro, por tanto, que la forma, lo que en un sentido amplio y seguramente impreciso llamamos forma - sean plazos, fórmulas o la mera constatación de requisitos-, tiene un alcance eminentemente medial y subordinado. Vano sería negar su enorme importancia, de modo que puede - ¿cómo no?ser objeto de estudio pormenorizado y requerir así la atención prevalente del investigador. Pero en la vida jurídica es siempre una importancia desde su posición medial y de subordinación. Aparece así condicionada a que cumpla el fin para el que se instauró. Sólo por él se justifica. Si queda desenganchada, si pierde amarras, se torna inservible, perturbadora, como barca a la deriva. Cuando afloja su funcionalidad es cuando la exigencia de forma degenera en formalismo, con toda la carga negativa que tiene la expresión: acumulación: innecesaria de actividades mediales — que siempre desgastan-, sobrecarga de

los Tribunales se han puesto tantas veces de relieve que se ha tendido a olvidar que tam-. bién era un destacado jurista.»

${ }_{5}^{5}$ Como muestra de remisión a las mismas véase, por todos, Montero Aroca, Análisis critico..., 91, quien, expresando la opinión general, señala: «La necesidad de la forma en el procedimiento responde a la propia naturaleza de éste. La forma es la condición necesaria para la certeza, el precio de la seguridad.» 
energía y de esfuerzo para nada. Lo que era prenda de garantía, al dejar de serlo la empece. Como yedras inútiles que se alimentan a costa del árbol. Es decir, la que ya no sirve, estorba. Y más cuanto más se acumula. Las formalidades inservibles no sólo no ayudan a la justicia, sino que, al contrario, la impiden y la contrarían. Lo que pudieron ser canales fluidos no son más que caños atascados que perturban e inundan, aunque sólo sea de papeles inútiles.

Aludía al comienzo a las leyes que cubren tres de los ámbitos jurisdiccionales destacados. Pero está claro que, con ser importante el texto de la ley, no es sólo cuestión de leyes. Recordaba don Gumersindo de Azcárate la vieja frase, tan cáustica como certera, que da en el clavo, de que «vale más tener leyes malas y jueces buenos que leyes buenas y jueces malos» ${ }^{6}$. Lo que quiero resaltar yo ahora es que la ley, con ser importante, es sólo un elemento más dentro de un mundo muy complejo. En el sistema jurisdiccional, realidad complicadísima, juegan leyes y personas, pero también hábitos y costumbres, incluso con frecuencia rutinas, inercias y aun meras situaciones que el paso del tiempo parece consolidar.

Ánte tal panorama, el esfuerzo del legislador poco alcanza, a no ser que encuentre un clima adecuado o logre dotarse de los impulsos necesarios para llegar con pleno conocimiento hasta el fondo. Se ha hablado mucho del ritualismo en el ámbito de aplicación, en el entorno, de la LEC o de la LECrim. Es de recordar también al respecto el dato de que el Tribunal Supremo, el gran órgano jurisdiccional unificador de criterios y cuyo impulso estaba llamado a ser decisivo, se nos ofrece preponderantemente en las jurisdicciones mencionadas como tribunal de casación: conocido es el ritualismo de que se ha hecho gala aquí. Bien está cuidar que el recurso de casación no se desboque, pero es unánime la opinión de los autores al reconocer cómo se ha rizado hasta la exageración el rizo del formalismo a propósito de tal recurso.

3. Conozco mejor, por mi especialización, el mundo del contenciosoadministrativo, del que ahora, también a vuela pluma, he de destacar, porque lo exige el curso de la exposición, unos cuantos puntos suficientemente aireados por los estudiosos. He de comenzar subrayando la sensación de desconcierto, de angustia, de frustración aún, que se produjo conforme se iba comprobando que las amplias expectativas abiertas por la LJ no sólo no se llevaban a la práctica y se desarrollaban, sino que, por el contrario, se desaprovechaban y quedaban obturadas, situación que dio lugar a una muy importante literatura, descriptiva o crítica cuando menos, alumbradora de nuevos caminos casi siempre.

Se suele recordar en estas lides un luminoso párrafo de la exposición de motivos de la LJ, el último, por cierto, que denota bien a las claras cómo los autores de la ley conocían el paño y trataron, por lo mismo, de dejar a mano los remedios. Dice, en efecto:

«Finalmente, merece destacarse el artículo 129 , que, siguiendo la orientación del nuevo texto, permite la subsanación de todos aquellos

- Véase ahora en el reciente volumen recogiendo obras de Azcárate, Municipalismo y regionalismo, IEAL, Madrid, 1979, pág. 108. 
defectos que pudieran concurrir en los actos de las partes. La ley considera que los requisitos formales se instituyen para asegurar el acierto de las decisiones jurisdiccionales y su conformidad con la justicia; no como obstáculos que hayan de ser superados para alcanzar la realización de la misma.»

El texto es excelente y no merece más que elogios, asumiendo además la que sería doctrina elemental acerca de las formalidades. De una parte está la expresión de la filosofía de los requisitos formales en el sentido instrumental antes glosado: "para asegurar el acierto», se dirá. Con la consiguiente advertencia ante las obvias disfunciones caso de olvidarse: «no como obstáculos que hayan de ser superados». De otra parte, la mención a la fórmula operativa para que no sea sólo cosa de palabras: el artículo 129 , que permite la subsanación de todos los defectos, y subrayo lo de todos. Ello, claro, «siguiendo la orientación del nuevo texto». Y es que, en efecto, el párrafo comentado no es sino el broche final de una línea reiteradamente expuesta a lo largo de la exposición de motivos de la ley. He aquí como muestra otros fragmentos del propio preámbulo, claramente coincidentes con el anterior, aun casi en las propias palabras.

A poco de iniciarse la exposición de motivos, en la justificación de la reforma se dirá:

«Así, se han (...) redactado los preceptos de la ley de modo tendente a evitar interpretaciones formalistas que, al conducir a la inadmisión de numerosos recursos contencioso-administrativos, comportaban la subsistencia de infracciones administrativas en pugna con la justicia, contenido del verdadero interés público y fundamento básico de toda organización política.»

Veamos aún otra muestra: En otro paso, al tratar del procedimiento contencioso-administrativo, y a propósito de la subsanación de defectos procesales, se dirá en el preámbulo:

«Se parte para ello de un principio: que las formalidades procesales han de entenderse siempre para servir a la justicia, garantizando el acierto en la decisión jurisdiccional; jamás como obstáculos encaminados a dificultar el pronunciamiento de sentencia acerca de la cuestión de fondo y así obstruir la actuación de lo que constituye la razón misma de ser de la justicia.»

De modo que, en cuanto a principios y razonamientos, no se quedaron cortos los autores de la ley: se palpa la abundancia; podría chocar incluso la reiteración. Los motivos, el motivo del antiformalismo en concreto, esa llamada a alcanzar pronunciamiento acerca de la cuestión de fondo, bien expuestos quedaron en la pieza. Pero no sólo explicaciones, no sólo palabras, que, en cuanto están brindando oportunidades a los juzgadores, ya es mucho: técnicas jurídicas también incorporadas con precisión a la letra de la ley, lo cual ya es determinante. Se aludía antes, en el primer fragmento transcrito, al artícu- 
lo 129 de la LJ. Convendrá que se lo recordemos al lector por si no lo tiene presente:

«1. Cuando se alegare que alguno de los actos de las partes no reúne los requisitos dispuestos por la presente ley, la que se hallare en tal supuesto podrá subsanar el defecto dentro de los diez días siguientes al que se le notificare el escrito que contenga la alegación.

2. Cuando el Tribunal apreciare de oficio la existencia de alguno de los defectos a que se refiere el párrafo anterior, dictará providencia en la que los reseñe y otorgue el mencionado plazo para la subsanación, con suspensión, en su caso, del fijado para dictar sentencia.

3. Si el defecto consistiese en no haberse interpuesto recurso de reposición, siendo éste preceptivo, y se hubiere denunciado esta omisión por la Administración demandada, el Tribunal requerirá al demandante para que lo formule en el plazo de diez días, y si se acreditara dentro de los siguientes haberlo deducido, quedará en suspenso el procedimiento hasta que se resuelva el recurso de reposición en forma expresa o transcurra el plazo a que se refiere el artículo 54.»

¡Qué no podía haberse hecho, de haberse querido, con preceptos como éste, con todo el impulso además que la exposición de motivos abastece! Pero la historia fue otra - a propósito del 129 de la LJ bien podría hablarse de «historia de una frustración» como prototipo de un clima general de no participación y de dirigismo-, y ha sido tantas veces contada que me excluye a mí de abundar en lo conocido. Sólo recordaré, para el lector no familiarizado con estos temas —aparte de remitirle a la literatura especializada ${ }^{7}$-, la frecuencia con que el Tribunal Supremo hizo gala de un exacerbado rigorismo formalista - y la expresión es del propio Tribunal Supremo ${ }^{8}$ - . Las enormes posibilidades del transcrito artículo 129 quedaron en no pocas ocasiones vaciadas de contenido, con la consiguiente secuela del florecimiento de los pronunciamientos que se limitaban a declarar la inadmisibilidad del recurso. Es decir, que no se entraba en el fondo de los asuntos. Se sacó de quicio, por citar una muestra, la exigencia de la necesidad del recurso de reposición -incluso en supuestos en que parecía obvio que podía prescindirse de él: ahí está, por ejemplo, el caso del artículo 35.2 de la Ley de Expropiación Forzosa y la jurispruden-

7 He aquí una muestra, por fuerza muy esquemática y breve, de trabajos que laboraron en la dirección apuntada, cada uno desde su concreto enfoque, y cuyos títulos, como regla, ya son muy expresivos: S. Alvarez Gendín, «El cómputo del plazo para interponer el recurso de reposición previo al contencioso-administrativo», en $R A P$, núm. 41, 1963, páginas 131 y sigs.; M. Clavero Arévalo, «El problema del previo pago en la reciente jurisprudencia», en $R A P$, núm. 41, 1963, págs. 169 y sigs.; E. García de Enterría, «Recurso directo contra disposiciones reglamentarias y recurso previo de reposición», en $R A P$, núm. 29, 1959, y ahora en su libro Legislación delegada, potestad reglamentaria y control judicial, Ed. Tecnos, Madrid, 2.a ed., 1981; N. Gómez de Enterría, «Meses naturales y meses de treinta días», en RAP, núm. 39, 1962; J. González Pérez, Administración Pública y libertad, Universidad Nacional Autónoma de México, 1971, y F. Sainz de Robles, «La legitimación de las Corporaciones en el proceso administrativo», en Revista de Derecho Procesal, enero-junio 1964.

${ }^{8}$ Véase la sentencia de la Sala $5{ }^{a}$ del TS, de 30 de enero de 1963. La estudiaba García de Enterría en el trabajo que cito en la nota siguiente, pág. 281. 
cia aperturista de la Audiencia Territorial de Madrid, que terminó siendo sofocada por el TS, o el del recurso contra reglamentos del artículo 39.3 (en relación con el 53.e) de la propia $\mathrm{LJ}$-, lo cual es grave, pero sobre todo lo destacable ahora es que se cegaron las oportunidades del 129 , pues como cuando se constataba la ausencia del recurso de reposición ya había transcurrido, por supuesto, cómo no - icómo si no fueran conscientes de ello los autores de la LJ! - , el breve plazo previsto para interponerlo, se fue a la interpretación - pasando por encima del espíritu y de la letra de la ley- de que no cabía ya la subsanación y que lo único que procedía, por ende, era proclamar la inadmisibilidad del recurso. $Y$ no digamos cómo se rizó el rizo, pasando a otro tercio, a la hora de contar en la práctica el previsto plazo de un mes: la falta de claridad legislativa facilitó, en una larga época, todo aquel episodio de si habían de ser de treinta días los meses y no de fecha a fecha, con la secuela inexorable, fruto de aquella rigurosísima interpretación, que no se entiende hoy cómo pudo llegar a ser posible, de que tan improvisada aduana hizo caer en la inadmisibilidad - es decir, sin oportunidad de pronunciamiento en cuanto al fondo- cantidades enormes de recursos. Del mismo modo, lo que sucedió con la interpretación de la legitimación a la hora de impugnar los reglamentos ilegales, o con otras modalidades similares. Rigorismo formalista llevado a numerosos aspectos del procedimiento que no es oportuno enumerar ahora, que vino a introducir, en definitiva, un clima de exacerbamiento, de formalismo, por utilizar la palabra ya apuntada, que de alguna manera vino a gravitar sobre todo el ámbito de la jurisdicción contencioso-administrativa. Y cuando alguna sentencia excepcional se destacaba, para apartarse de aquel clima, aprovechaban los autores para jalear al Tribunal, para animarle, subrayando como modelo y línea de conducta lo que, por desgracia, al menos en toda la época inicial, que se prolongó generosamente, sólo habían sido decisiones de coyuntura y sin duda excepcionales dentro de la práctica generalizada. Paradigmático es así el brillante comentario jurisprudencial que, muy en línea con anteriores aportaciones suyas, dedicó en 1963, con esa intención clara de resaltar sentencias que encajaban dentro de la línea abierta por la clara intencionalidad de la LJ, el profesor García de Enterría, y cuyo título es de sobra expresivo de esta constatación-deseo, «El principio de la interpretación más favorable al derecho del administrado al enjuiciamiento jurisdiccional de los actos administrativos» ${ }^{9}$. Se alentaba así la introducción, como auténtico principio general del derecho, de la regla in dubio pro actione, principio pro actione o favor actionis. Con toda delicadeza, se trata de recordarles a los jueces algo obvio, usando para ello sus propias palabras, su propio razonamiento:

«... será obligado concluir - escribía García de Enterría- lo que el Tribunal Supremo, en una ejemplar manifestación de autoconciencia de su función, ha comenzado a proclamar: que lo esencial es llegar al fondo de los recursos, a lo que deben subordinarse decididamente las formalidades procesales, evitando su sustantivación; que las excepciones a la admisión de los recursos son de interpretación no ya enunciativa o declarativa, sino positivamente restrictiva en cuanto reglas odiosas

9 Véase RAP, núm. 42, págs. 267 y sigs. 
por contradecir o limitar ese derecho fundamental y natural; que lo esencial es hacer posible el ejercicio de dicho derecho, para lo cual debe buscarse siempre en toda cuestión disputada sobre la materia la interpretación precisamente más favorable a este efecto. Una vez que se nos han hecho explícitas por la declaración jurisprudencial, vemos claro, en efecto, que esas reglas son la expresión no ya de una simple tendencia doctrinal más o menos simpática, sino del orden profundo del Derecho, de las estructuras objetivas y ónticas sobre las que se apoya el sistema jurídico de la naturaleza de las cosas, en el sentido más radical y profundo de esta expresión» ${ }^{10}$.

He aquí una elegante y provechosa manera de buscar la superación de unas carencias. Frente a la generalizada realidad de las declaraciones de inadmisibilidad, frente al detenerse, $\tan$ frecuente, sin entrar en el fondo del asunto, frente al frondoso imperio del formalismo, se va a teorizar y propugnar la regla pro actione, revistiéndola además de la consistente vestimenta de caracterizarla como un principio general del derecho.

4. El ejemplo del contencioso-administrativo, siempre que se salven las distancias, es sumamente ilustrador, pues no en balde la ley reguladora constituye el cuerpo procesal más reciente de los tres que he mencionado al inicio de estas páginas. Por eso que, volviendo a los planteamientos generales, sin dejar de desconocer importantes excepciones y ejemplos personales muy valiosos, lo cierto es que la sombra del ritualismo se ha venido proyectando con intensidad en el panorama español de la justicia. Por lo mismo, y sin olvidar las características tan destacadas a la par que peculiares del TC, lo que nos lleva a guardar las debidas distancias, me parece del mayor interés la experiencia que depara la más reciente modalidad jurisdiccional que se ha puesto en marcha entre nosotros ". Es así como venimos al sistema de la justicia constitucional, advirtiendo muy mucho que sería empobrecerlo demasiado querer identificar sin más TC con jurisdicción constitucional. Aposta he querido abordar este aspecto -y empalmo ahora con lo que decía antes acerca de las razones que me han movido- por la sencilla razón de que me parece ejemplar. Se trastrocan radicalmente los planteamientos tradicionales, produciéndose, con la mayor naturalidad, además, un giro de 180 grados. Por eso quería insistir sobre este aspecto. Por eso quería llamar la atención. Porque, aparte del sano ejercicio de colaborar a que se conozca la verdad, nos ha de permitir, del mismo modo, extraer conclusiones de señalada entidad. Voy a tratar así de desarrollar mi tesis de cómo, aun a pesar del todavía breve período de funcionamiento, el sistema de la jurisdicción constitucional se caracteriza, muy marcadamente, por sus altas cotas de antiformalismo, es decir, por el deseo conscientemente asumido desde el principio de que las exigencias formales no pierdan el sen273.

${ }^{10}$ E. García de Enterría, El principio de la interpretación más favorable, cit., págs. 272.

is Véase luego, en nota 55, cómo autocalifica el propio TC su posición dentro de la estructura del Estado. Muy interesante, entre la bibliografía más reciente la monografía de Raúl Bocanegra Sierra, El valor de las sentencias del Tribunal Constitucional, IEAL, Madrid, 1982, especialmente, ahora, págs. 161 y sigs. 
tido medial que debe caracterizarles, resaltando la intención de procurar a toda costa que el Tribunal llegue a pronunciarse sobre el fondo. Conocer el fondo de la cuestión. De ahí que no sea mi intención ocuparme de los que suelen denominarse aspectos sustantivos - tan relevantes por demás, tan atractivos-; para ceñirme en mi análisis al aspecto procedimental apuntado.

A tal efecto voy a desarrollar mi exposición exponiendo primero las previsiones que se han adoptado desde la perspectiva normativa. Es decir, que es lo que ha previsto la LOTC - lo mismo que antes se analizó la respuesta dada por el legislador con la LJ-. Pero como no basta el simple análisis de la ley -en cuanto un sistema legal puede ser traicionado por la praxis-, pasaré luego a realizar un muestreo sobre la jurisprudencia ya producida, así como. sobre el clima general que se va asentando.

5. Para exponer la solución adoptada por la LOTC me voy a ceñir muy escuetamente a los puntos de interés inmediato. Quiero decir con ello que prescindo de planteamientos generales, de modo que valga una remisión global a las exposiciones de conjunto sobre la justicia constitucional ${ }^{12}$. La pregunta en concreto para centrar el tema va a ser la siguiente: ¿qué previsiones adopta. la LOTC para asegurar que las exigencias formales mantengan su carácter medial y no degeneren, por tanto, en formalismo? Veíamos antes -en el modelo de contencioso-administrativo desarrollado- cómo el ritualismo lograba, en gran parte, su victoria al conseguir la sanción de inadmisibilidad, con lo. que los requisitos formales alcanzaban un valor prepotente en el conjunto de un proceso, llegando nada menos que a impedir el conocimiento del fondo del asunto. Sobre este modelo voy a construir también ahora mi análisis, advirtiendo que las categorías dogmáticas están aquí mucho menos elaboradas. Por tanto, el punto de partida adoptado va a hacer que sea a propósito del recurso. de amparo donde resulte muy fácil -y de mayor interés también - estudiar el problema, lo que no quita para que alguna de las observaciones resulten predicables de las otras modalidades que abarca la justicia constitucional.

Según mi punto de vista, puede extraerse de la LOTC un triple esquema. Describiré así: A) cómo al regularse los recursos se establece un conjunto de presupuestos, requisitos y exigencias; B) cómo se contemplan, casi correlativamente, los supuestos de inadmisibilidad, y $\mathrm{C}$ ) cuáles son, por último, las incorrecciones subsanables.

${ }^{12}$ Una visión de conjunto sobre los aspectos procesales de la LOTC puede verse en J. González Pérez, Derecho procesal constitucional, Ed. Cívitas, Madrid, 1980. De entre la abundante bibliografía que está surgiendo ya en torno al TC y en torno a la LOTC más en concreto, se encontrarán aportaciones interesantes, y a ellas me remito, en los tres volúmenes que bajo el título El Tribunal Constitucional, Instituto de Estudios Fiscales, Madrid, 1981, recogen la documentación de las Jornadas de la Dirección General de lo Contencioso del Estado, de mayo de 1980. Con carácter general, también, para muchos. de los problemas que se han de abordar en estas páginas, la citada monografía de Raúl Bocanegra, El valor de las sentencias del Tribunal Constitucional. 
6. Paso ya a desarrollar el esquema apuntado, advirtiendo que adoptaré sobre todo una postura de tono descriptivo.

A) Aludiré ante todo al conjunto de exigencias que incumben al recurrente a la hora de formalizar su recurso. Ni se enumerarán todas ni la mención tiene una finalidad de sistematización científica, por lo que utilizo la expresión «requisitos» que puede albergar a todas, sin necesidad de mayores precisiones. El estudio de la LOTC nos depara, entre otros, los siguientes -advirtiendo que, mientras no indique otra cosa, hay que referir a dicha ley las citas de artículos-, arrancando además, como punto de partida, sin perjuicio de otras remisiones, del recurso de amparo contra autoridades públicas en general (art. 43.1):

a) Que se haya agotado la vía judicial procedente (art. 43.1).

b) Fundarse sólo en la infracción de los preceptos constitucionales susceptibles de amparo (art. 43.3).

c) Para el supuesto de que la violación provenga directa e inmediatamente de un órgano judicial se precisa que en el proceso se haya invocado formalmente el derecho constitucional vulnerado (art. 44.1.c).

d) Plazo de veinte días a contar de la notificación de la correspondiente resolución judicial (art. 43.2) o de la notificación de la resolución que impone la obligación de prestar el servicio militar para el supuesto de la objeción de conciencia (art. 45).

e) Se consideran legitimados, aparte del Defensor del Pueblo -para cuando exista- y el Ministerio Fiscal, quienes hayan sido parte en el proceso judicial correspondiente (art. 46.1.b).

f) El artículo 49.1 prescribe que el recurso de amparo se iniciará con la demanda, que habrá de contener la exposición de los hechos, la mención de los preceptos considerados infringidos, así como la concreción del amparo que se solicita.

g) Entre los documentos a aportar con la demanda importa mencionar -entre otros de los que prescindiremos- el que acredite la representación del solicitante de amparo (art. 49.1.a). Las menciones anteriores se extraen del título III de la LOTC, referido al recurso de amparo. En el título VII - disposiciones comunes sobre procedimiento- se puntualiza que quienes comparezcan deberán conferir su representación a un procurador y actuar bajo la dirección de letrado, si bien los licenciados en dedecho, cuando de sus intereses o derechos se trate, podrán comparecer por sí mismos (art. 81.1). Debiendo recordar también que los órganos o los conjuntos de parlamentarios legitimados para promover procesos constitucionales actuarán en los mismos representados por el miembro o miembros que designen o por un comisionado nombrado al efecto (art. 82.1).

7. Como segundo término del esquema - B - figura, decíamos, lo referente a la inadmisibilidad. Es normal que el Tribunal cuente con esta arma defensiva, por así decir (con lo que de nuevo aparece la similitud con el modelo de lo contencioso-administrativo utilizado). Obvio resulta -ya quedó apuntado- que es preciso centrar el proceso y proporcionar, del mismo modo, una serie de datos que redundan, por ende, en el cumplimiento de un conjunto de exigencias. Hasta aquí los requisitos formales imprescindibles. ¿De- 
generación en formalismo? En un análisis lógico ése sería el paso siguiente, posible pero no necesario. Permanezcamos todavía allí donde los requisitos formales aparecen como dotados de plena lógica. Para contrastar su alcance conviene tener en cuenta lo que dispone el artículo 50:

«Uno. La Sala, previa audiencia del solicitante de amparo y del Ministerio Fiscal, por plazo común que no excederá de diez días, podrá acordar motivadamente la inadmisión del recurso si concurre alguno de los siguientes requisitos:

a) Que la demanda se haya presentado fuera de plazo.

b) Que la demanda presentada sea defectuosa por carecer de los requisitos legalos o no ir acompañada de los documentos preceptivos, sin perjuicio de lo establecido en el artículo ochenta y cinco, dos.

Dos. También podrá acordarse la inadmisibilidad, con los requisitos de audiencia señalados en el número anterior, en los siguientes supuestos:

a) Si la demanda se deduce respecto de derechos o libertades no susceptibles de amparo constitucional.

b) Si la demanda carece manifiestamente de contenido que justifique una decisión por parte del Tribunal Constitucional.

c) Si el Tribunal Constitucional hubiera ya desestimado en èl fondo un recurso o cuestión de inconstitucionalidad o un recurso de amparo en supuesto sustancialmente igual.

Tres. Contra el acuerdo de inadmisión de una demanda de amparo constitucional no cabrá recurso alguno.»

Prescindiré ahora de este párrafo tercero, buena prueba de la confianza depositada en el TC; también de su responsabilidad, pues, al fin y al cabo, el control de la inadmisibilidad es una válvula poderosísima para regular el alcance efectivo del recurso de amparo como institución. Lo que interesa destacar sobre todo es que este artículo 50 contiene de hecho un correlato de las exigencias que hemos visto antes dispersas por diversos preceptos. Es algo así como el reverso, de modo que, ya sea a través de la mención expresa, ya sea por las fórmulas de remisión global, la debilidad en cualquiera de los requisitos antes recogidos puede concluir en inadmisibilidad. El punto de partida, por tanto, no deja desarmado al Tribunal ante posibles irregularidades, ante incongruencias notables. Esta es la otra faceta de la regulación de los requisitos formales. Es obvio que el Tribunal va a estar dotado de muy amplias facultades, que podrá ejercer luego en uno u otro sentido. Pero antes de pasar al ejercicio por parte del Tribunal, aún en la esfera de la regulación, quiero llamar la atención acerca de algunos puntos, tres en concreto.

a) La fórmula que ha utilizado la LOTC al regular las inadmisibilidades es una fórmula intencionadamente elástica que, por lo mismo, deja en manos del Tribunal un amplio ámbito de interpretación. El legislador estima prudente attibuir tal confianza al Tribunal, decisión que parece altamente encomiable. Contrástese, por ejemplo, la modalidad opcional del artículo 50 de la LOTC 
—La Sala... podrá acordar» ${ }^{13}$ - con la rigidez que denota el correlativo artículo 62.1 de la LJ: «El Tribunal... declarará no haber lugar a la admisión.» Y lo mismo cuando el pronunciamiento se deja para el momento de la sentencia: «La sentencia declarará la inadmisibilidad...» (art. 82 de la LJ).

Sin duda cabe siempre interpretar elásticamente una fórmula brusca y tajante. Pero no está mal que las propias palabras de la ley dejen ya el camino claro.

b) Decía que el artículo 50 viene a marcar el contrapeso a los requisitos formales exigidos al recurrente. En efecto, todos los requisitos que antes he enunciado tienen un reflejo en el precepto que sirve de apoyo a las inadmisibilidades. Encaje, por tanto, de la pieza cóncava y de la convexa. Pero no del todo; la regulación de las inadmisibilidades tiene algo más, tiene un inciso que escapa o que está más allá de la esfera de comportamiento subjetivo del recurrente, que no depende, por tanto, de él ni de sus fallos u omisiones. Quiero referirme así a lo que se expresa en la letra $c$ ) del párrafo segundo del precepto. Recuérdese:

«Si el Tribunal Constitucional hubiera ya desestimado en el fondo un recurso o cuestión de inconstitucionalidad o un recurso de amparo en supuesto sustancialmente igual.»

Aparece aquí, entre otros aspectos, el poder de regulación que se otorga al propio TC para hacer más caudalosa o más menguada la corriente de los recursos de amparo. Ha sido muy importante, en cuanto al fondo, el papel movilizador que ha desempeñado el TC en su todavía corto período de existencia a través del instrumento de las sentencias de amparo. Hay que reconocer, sin miramientos, esta labor dinamizadora de potenciar amparos a derechos y libertades violentados, ayudando especialmente a superar las zonas de sombra. Pero yo creo que aquí su labor debe ser una labor residual y de orientación. Bien que haya roto los hielos y haya abierto brecha. Ahí debe estar siempre, en una vigilancia superior. Facilitando el camino $\longrightarrow$ marcando los quiebros pertinentes - para que el peso decisivo en los amparos. lo lleven los tribunales ordinarios. Aunque sólo sea - sin entrar ahora en polémicas doctrinales ${ }^{14}$ - porque el TC tiene muchas cosas que hacer. $\mathrm{Y}$ doce miembros son

${ }^{13}$ La fórmula ya estaba en el proyecto de LOTC -entonces era el artículo 54-, aunque con un ligeto matiz: donde el texto definitivo ha dicho «podrá acordar motivadamente la inadmisibilidad», el proyecto sugería «podrá acordar motivadamente la inadmisión».

14 Buen apoyo para cuanto vengo diciendo lo constituye la matización que la propia Constitución introduce cuando se ocupa del recurso de amparo - cosa que no hace, patentemente, cuando se mencionan las otras competencias del Tribunal-. La matización de la letra $b$ ), del párrafo primero, del artículo 161 , va a implicar la competencia del Tribunal, para el recurso de amparo, «en los casos y formas que la ley establezca». No es posible hallar algo similar ni en la letra $a$ ) ni en la letra $c$ ). Tampoco en el supuesto del párrafo segundo del precepto.

En la misma línea hay que recordar el «en su caso», del párrafo segundo del artículo 53, cuando del recurso de amparo ante el TC se trate - no, en cambio, cuando se tramite ante los tribunales ordinarios, supuesto para el que no hay salvedad alguna-. Para mi postura en la discusión constitucional - contraria a encomendar el amparo al TC-, así como para los pormenores de dicha discusión en el Senado, me remito al capítulo «Contra el recurso de amparo», de mi libro - todavía inédito, por desgracia- Materiales para una Constitución (los trabajos de un profesor en la Comisión Constitucional del Senado). 
sólo doce miembros, por buenos servicios de que disponga — siendo como es decisivo que se mantenga un ritmo de rapidez (que no se perpetúen causas: poco será lo que se insista sobre esta faceta, lacra frecuente de lós sistemas jurisdiccionales) ${ }^{15} \mathrm{y}$, a la par, que los miembros discutan, en efecto, los diversos asuntos, como es obvio que hasta ahora lo hacen-.

Los contrapesos de los sistemas tienen que llevar a la lógica de que cuando se haya concedido un amparo no tenga que volver al TC ningún «supuesto sustancialmente igual» ${ }^{16}$. Del mismo modo, y volvemos al punto del precepto que nos ocupa, cuando se haya producido una desestimación, cuando el Tribunal haya ya adoptado postura acerca de algún aspecto - y la desestimación se lleva expresamente al fondo, de modo que no cabe dejar imprejuzgado un problema por irregularidades de forma que ocasionen la inadmisibilidad-, cuando haya ya un pronunciamiento razonado, no tiene sentido seguir entreteniendo al Tribunal Constitucional. De ahí que surja este nuevo motivo de inadmisibilidad. Buscando parangones, la letra $c$ ) del artículo 50.2 de la LOTC nos depara un supuesto de mucha mayor amplitud, de carácter mucho más vasto que el de la letra $d$ ) del artículo 82 de la LJ, que impone en la sentencia la declaración de inadmisibilidad en el caso de «que recayere sobre cosa juzgada». No es tanto el dato de la coincidencia subjetiva —además de la objetiva-, que sin duda quedaría también incluida en la fórmula de rechazo; no se trata sólo, en resumen, de que un recurrente vuelva sobre el mismo caso o sobre algo muy similar ${ }^{17}$, sino que la regulación se lleva mucho más lejos, llegando a prescindirse de los datos subjetivos para parar mientes tan sólo en la coincidencia o, mejor, similitud objetiva del «supuesto». Si en una ocasión se rechazó un problema similar, el legislador le brinda al TC, en reconocimiento al relieve institucional de sus fallos, la oportunidad de no seguir entreteniendo su tiempo con tal encomienda. Salvedad que resulta acertada si se tiene en cuenta la frivolidad con que algunos profesionales del Derecho embarcan a sus

${ }^{15}$ Yo mismo he insistido con frecuencia en los negativos efectos que, desde el panorama general de la Administración de Justicia, representaba la enorme duración de los expedientes en los supuestos de conflictos jurisdiccionales. Véase, últimamente, mi ponencia citada, La Ley de Conflictos Jurisdiccionales tras la entrada en vigor de la Constitución.

${ }_{16}$ Bernard Schwartz, en su interesante ensayo sobre Los diez mejores jueces de la bistoria norteamericana, cit., ha destacado, así, esos fallos relevantes que logran luego cascadas de decisiones de tribunales inferiores, que crean, incluso, un clima nuevo: «El Tribunal Warren - dirá así, pág. 90- amplió el contenido material de los derechos individuales, dándoles un significado menos restringido del que hasta entonces habían tenido en el Derecho norteamericano. La protección de los derechos y libertades públicas pasó a ser el centro de la Constitución vivida en la actualidad.»

En el mismo sentido, véase, abundantemente, García de Enterría, «La posición jurídica del Tribunal Constitucional en el sistema español: posibilidades y perspectivas», ahora en su libro La Constitución como norma y el Tribunal Constitucional, Ed. Cívitas, Madrid, 1981, págs. 145 y sigs.

${ }_{17}$ A la «cosa juzgada», como prototipo de coincidencia subjetiva -además de objetiva-, que, en el sistema de la $\mathrm{LJ}$, ocasiona la inadmisibilidad, hay que añadir el supuesto de «los actos que sean reproducción de otros anteriores que sean definitivos y firmes y los confirmatorios de acuerdos consentidos...», que, al estar incluidos en la letra a) del artículo $40 \mathrm{LJ}$, deberán provocar la inadmisibilidad, a tenor de lo que establece la propia $\mathrm{LJ}$, en el artículo 62, que reclama también tal efecto, cuando consta que se deduce «el recurso frente a alguno de los actos relacionados en el artículo $40 \ldots$... 
clientes, casi como si de cruceros de placer se tratara, en aventuras de recursos. Surge de nuevo ese poder de regulación que el TC ha recibido, como antes decía, para controlar el flujo de los recursos de amparo. Con la particularidad de que si, por cualquier razón, el Tribunal quisiera rectificar jurisprudencia anterior, la fórmula elástica adoptada a la hora de pronunciar inadmisibilidades le deja siempre abierta la puerta para pronunciarse allí donde lo tenga por conveniente.

c) Hay un tercer punto en el artículo 50 de la LOTC que debe recogerse ahora. La inadmisibilidad se proclama, sí, pero con una salvedad, al menos en lo que se refiere a los requisitos de la demanda: «sin perjuicio de lo establecido en el artículo ochenta y cinco, dos». Esta llamada reenvía a otro título de la ley, el que contiene las disposiciones comunes sobre procedimiento -el VII- ¿ ¿Y adónde conduce el reenvío? Conduce nada menos que a «los supuestos subsanables». De modo que la regulación de las inadmisibilidades no es cerrada, sino que mantiene esta línea de conexión. Es así como pasamos a analizar la tercera parte del esquema propuesto.

8. C) El artículo 85 se abre señalando cómo «la iniciación de un proceso constitucional deberá hacerse por escrito fundado en el que se fijará con precisión y claridad lo que se pide». Es, por tanto, una advertencia de valor general para cualquiera de las modalidades de proceso constitucional - de modo que las puntualizaciones que establece el artículo 49 , antes visto, en relación con la demanda para el recurso de amparo serían mera concreción de esta regla- $\mathrm{Y}$ en ese contexto viene el párrafo que nos interesa, redactado como sigue:

«Dos. En los supuestos subsanables a que se refiere el artículo cincuenta de la presente ley, el Tribunal deberá notificar al recurrente los motivos de inadmisión que hubiere con objeto de que, dentro del plazo de diez días, pueda subsanar los supuestos advertidos.»

La mención a los supuestos subsanables se ofrece como algo ya sabido y hallamos en el precepto un reenvío - que va a resultar recíproco- al artículo 50. En seguida vendré sobre el argumento. Pero no se agotan con estos dos preceptos entrelazados las posibilidades de saneamiento. Antes debo recordar que hay otro artículo que va a proporcionar gran juego también a la hora de las subsanaciones, con destacado peso, por tanto, a la hora de obviar inadmisibilidades. Se trata del artículo inmediatamente anterior, el 84, que dispone:

«El Tribunal, en cualquier tiempo anterior a la decisión, podrá comunicar a los comparecidos en el proceso constitucional la eventual existencia de otros motivos distintos de los alegados, con relevancia para acordar lo procedente sobre la admisión o inadmisión y, en su caso, sobre la estimación o desestimación de la pretensión constitucional. La audiencia será común, por plazo no superior al de diez días, con suspensión del término para dictar la resolución que procediere.» 
El estudio de los preceptos mencionados ${ }^{18}$, que evidencian cómo el legislador ha querido sustentar un claro impulso antiformalista ${ }^{19}$, me lleva, con más detalle, a formular las cuatro consideraciones que expongo a continuación.

a) El juego y el reenvío recíproco que entre sí se hacen los artículos 50 y 85.2 nos sitúa claramente ante un hecho de doble faz. De una parte, se reconoce sin duda que existen «supuestos subsanables». Es inequívoca la mención del segundo de los preceptos citados. Pero, de otra, apenas nada se concreta para saber cuáles hayan de ser tales supuestos subsanables. La ley ni pormenoriza ni se ha detenido a concretar. Es como si la LOTC diera por sentados cuáles son. ¿Serán todos los comprendidos en el ámbito de la letra $b$ ) del párrafo segundo del artículo 49, es decir, todos los referentes al contenido de la demanda y a los documentos que deben acompañarla? Pero ¿serán sólo ésos? ¿Hasta dónde pueden llegar, por ejemplo, los efectos del artículo 94 o de otros preceptos? No voy a pretender ahora aclarar los interrogantes. Quede sólo constancia de esta inconcreción de la ley y de este vacío que deja espacio para una ulterior interpretación.

b) La existencia de este vacío, de posible interpretación, nos abre camino a otra consideración. Sin perjuicio de la fuerza interpretativa de los argumentos de la doctrina, está claro que el TC ha recibido la importante facultad de rellenar esa partitura en blanco, dándole mayor o menor amplitud. No sé si fue consciente la intención, pero el hecho es que el resultado conduce a esta fórmula abierta. Con un riesgo innegable. De primar en los intérpretes un talante puntilloso y de supervaloración del detalle, podía resultar un clima de formalismo, es decir, de restricción en cuanto al acceso al fondo. Pero también cabría apostar por la carta contraria. Con una preocupación sincera por la búsqueda de la justicia de fondo, la indeterminación podía producir salutíferos efectos. Y tal parece haber sido la jugada resultante. La identificación de los miembros del Tribunal en el espíritu de la Constitución parecía garantizar holgadamente la predisposición para instar la búsqueda de la justicia de fondo. El riesgo sería más bien un riesgo controlado.

c) Tiene un cierto interés recordar alguno de los avatares de la elaboración de los preceptos estudiados, los entrelazados artículos 50 y 85.2 en concreto.

${ }^{18}$ Sin ningún afán de agotar el argumento, aún podría recordarse otro precepto de la LOTC en clara línea de superación de las irregularidades procedimentales. Me refiero al artículo 94, que establece: «El Tribunal, a instancia de parte o de oficio, deberá antes de pronunciar sentencia, subsanar o convalidar los defectos que hubieran podido producirse en el procedimiento.»

El precepto, en su forma originaria -artículo 99, entonces-, era más elástico y permisivo en cuanto se podía actuar «en cualquier tiempo». Esta sería la fórmula aprobada por el Pleno del Congreso, como artículo 94 ya. En el Senado, UCD presentaría una enmienda - la número 89-, objetando lo de «en cualquier tiempo», que resultaría aceptada en Comisión por la Ponencia. Se llegá allí ya a la fórmula que sería la definitiva, introduciéndose, al mismo tiempo, la expresión deberá donde antes decía podrá.

${ }^{19}$ A diferencia de lo sucedido con el luminoso párrafo final de la Exposición de Motivos de la LJ, en el preámbulo que ofrecía el proyecto de LOTC, tal y como apareció en el BOCG de 24 de mayo de 1979, preámbulo que luego no accedería al texto definitivo de la ley, no hay alusión alguna ni directa ni indirecta -si bien es cierto que el tal preámbulo ra breve y sólo se refería a alguna de las facetas más destacadas, que, por supuesto, eran muy otras- a la idea de antiformalismo, a la aspiración de superar el ritualismo o al peso descompensado de las formalidades. 
Por de pronto, entendiendo como entiendo que es positiva la facultad de subsanación, destacaré la suerte de que no prevaleciera la enmienda que presentó en el Congreso de los Diputados el Grupo de Minoría Catalana -la número 184-, que pretendía la desaparición del entonces párrafo segundo del artículo 90 del proyecto, que, con distinta redacción, ofrecía ya el núcleo del que ha pasado a ser artículo $85.2^{20}$.

Por fortuna, el precepto no se suprimió. La atención de que fueron objeto, desde otras perspectivas, los dos artículos estudiados propició el que se alcanzara una mejora sustancial de la primitiva redacción, sin que haya desaparecido del todo la sensación de que falta alguna pieza en el acoplamiento.

En efecto, la fórmula resultaba más restrictiva en el proyecto por mor de la redacción que ofrecía el precepto sobre la inadmisibilidad, actual artículo 50, que figuraba entonces como 54. El apartado $b$ ) del párrafo primero -aludiendo directamente a la inadmisibilidad - figuraba así redactado:

«Cuando la demanda presentada sea defectuosa por carecer de los requisitos legales o no ir acompañada de los documentos preceptivos -hasta aquí hay casi coincidencia-, siempre que los defectos no se subsanen en el plazo mismo de la audiencia.»

Esta redacción pasaría a través del Congreso de los Diputados, pero al fin sería modificada en el Senado. Senadores vascos, en su enmienda número 3, objetarían lo siguiente:

«Es una ingenuidad pensar que en el plazo de una audiencia puede subsanarse el error cometido por un recurrente de Almería o de Galicia.

La redacción dada sólo es útil para los recurrentes de Madrid.

Este artículo debe quedar en consonancia con lo que establece el artículo 85.»

Y pretendían llegar a un plazo más amplio que el de la audiencia, proponiendo que las últimas palabras del párrafo cuestionado fueran sustituidas por las siguientes:

\section{«... en el plazo que al efecto se señale».}

Por su parte, la UCD objetaba la redacción del párrafo segundo del artículo 85, con propuesta -era la enmienda núm. 81- del tenor siguiente:

«En los supuestos a que se refieren los números 1 y 2 del artículo 50 de la presente ley, el Tribunal deberá poner de manifiesto al recurrente los motivos de inadmisión que advirtiere con objeto de que, dentro del plazo de diez días, pueda subsanarlos.»

${ }^{20} \mathrm{La}$ justificación que se ofrecía en la enmienda, no muy apurada técnicamente, por cierto, era la siguiente: «Si el rechazo es una inadmisión, la previsión es innecesaria. Si es distinta, no se sabe qué es. La advertencia previa o subsanación debe reconducirse, en todo caso, a los términos genéricos del artículo 85 , sin olvidar que la comparecencia ante el Tribunal requiere la asistencia letrada y se hace mediante procurador.» 
Es así como, aceptándose la idea de ambas enmiendas, iban a modificarse los preceptos, llegándose a la fórmula final que ya nos es conocida, con este reenvío recíproco - y la sensación de que falta alguna pieza en el rompecabezas- entre el 50.1.b y el 85.2.

d) Para terminar con la exposición de los planteamientos legales quiero destacar, por último, el generoso papel antiformalista que puede deducirse del artículo 84 - la mera comparación con los preceptos correspondientes que regulan la casación en cada uno de los órdenes jurisdiccionales evidencia una distancia de años luz-. El Tribunal tiene la facultad de comunicar a los comparecientes - como se recordará- la existencia de otros motivos distintos de los alegados.

Al regular la LOTC el recurso de inconstitucionalidad, el artículo 39.2 se cuida mucho de dejar establecido, con recepción neta del principio iura novit curia, que la sentencia podrá fundarse en la infracción de cualquier precepto, «haya o no sido invocado en el curso del proceso» (y eso que al formular el recurso de inconstitucionalidad se exige «precisar el precepto constitucional que se entiende infringido», art. 33). Tal facultad no se contiene, en cambio, al regularse la sentencia en el recurso de amparo.

Por supuesto que es muy distinto el significado de uno y otro recurso - tampoco insistiré ahora en lo que son planteamientos generales conocidos-. Es, ciertamente, diferente el papel institucional de «legislador negativo» que el de amparador de un derecho fundamental vulnerado. Aparte de que en este último caso suele haber partes enfrentadas, manteniendo, previsiblemente, puntos de vista dispares. Con todo, aunque el de amparo, como expliqué antes, sea un recurso con una innegable vocación de excepcionalidad, puesto que llega al Tribunal - cuando llega-, parece de interés que la ley deje claro que tan relevante órgano constitucional no queda vinculado en lo jurídico -en lo constitucional más aún - por el deseo -o el conocimiento o el desconocimientode quien demande el amparo, sino que queda investido como defensor globalizado de la constitucionalidad. Aunque haya una controversia de parte está muy bien - no es preciso resaltar el alcance institucional que cobra cada decisión - que se haya marcado la diferencia con otros órdenes de recursos - la casación, por ejemplo- y que se abran con holgura las ventanas de la tutela de la constitucionalidad. Debiendo advertirse además que, aunque haya partes con posibles puntos de vista contrapuestos, hay dos nuevos aspectos que cabe considerar. Por de pronto se abre una audiencia común que ha de ser del mismo tiempo de duración para todos «los comparecidos». Pero, en segundo lugar, este facilitar la tarea de una de las partes se explica, sin lugar a dudas -aunque la «parte contraria», que, de alguna manera, ve debilitada su postura, sea uno de los poderes públicos-, por la sencilla razón de que la defensa de la constitucionalidad, de la que es responsable máximo el TĆ, está por encima -en estas lides institucionales- del punto de vista de cualquier poder público. Así de sencillo, aunque pueda resultar riguroso o incómodo en ocasiones. El único inconveniente que le veo yo a tan destacable facultad es el de que llegue a haber quien se lamente de que, mientras a otros se les facilitó su tarea, recibiendo la inspiración de tan cualificado espíritu santo, en su caso no se produjo tal insinuación. Pero aquí sí que es preciso confiar en la pruden- 
cia de quien tiene entre sus misiones la de velar por que se cumpla el principio de igualdad ante la ley.

También en la discusión de la ley el precepto fue objeto de controversia. En concreto, hubo una enmienda en el Congreso de los Diputados - la 183-, de Minoría Catalana de nuevo, que pretendía, sin más, la supresión del precepto (que entonces era el art. 89, con redacción muy similar a la que ha prevalecido). Tal propuesta se apoyaba en la siguiente justificación:

«La iniciativa del Tribunal Constitucional, por encima de la petición que concretamente se le formula, convierte a aquél en una segunda instancia política bajo la apariencia de un orden jurisdiccional. Contraria al principio de justicia rogada, interpreta extensivamente y abusivamente la Constitución y afecta decididamente a la seguridad jurídica.»

Por lo que antes he indicado, no comparto el razonamiento ${ }^{21}$. Estimo así que fue ventajoso que la enmienda no prevaleciera.

De modo que, por concluir con este punto, valoro positivamente, desde la perspectiva antiformalista, la oportunidad que brinda el artículo 84 , que puede dar gran juego tanto a la hora de dilucidar inadmisibilidades como a la de decidir el fondo de los asuntos. De otro lado, el hecho de que el precepto se halle ubicado en un título de aplicación general diversifica sus efectos a todos los procesos constitucionales, atañendo, por supuesto, entre ellos, al recurso de amparo.

\section{III}

9. Termino así con la exposición de la respuesta normativa. Creo que, sin duda, del conjunto de preceptos estudiados - y aún quedan otros en la misma dirección- cabe deducir un amplio sentido antiformalista cuyos alcances están llamados a resultar del mayor interés, contando como se cuenta - luego se insistirá sobre ello- con poderosos motores que alientan el acceso a la justicia de fondo. He insistido más en el recurso de amparo y en las causas de inadmisibilidad, pero debe quedar claro que el impulso antiformalista no se circunscribe sólo a ellas. Tiene un alcance mucho más amplio, general, podemos decir. Del mismo modo que resulta obvio que este afán por superar los ritualismos no es exclusivo del recurso de amparo ${ }^{22}$, sino que va a cubrir todo el terreno de

${ }^{21}$ No deja de resultar paradójico que uno de los primeros casos en que el TC hizo uso de la facultad del artículo 94 fuera un amparo instado desde Cataluña por un grupo de sindicalistas, amparo que lograría sentencia favorable a los recurrentes - de fecha 8 de junio de 1981 - y en el que, como más adelante señalaré, jugaría su papel la utilización de la sugerencia instada por el Tribunal. Claro que a lo mejor la longitud de onda entre los sindicalistas y los diputados de Minoría Catalana rayaba a notable distancia.

2 Aunque ofrezca también otros matices, presenta interés, desde la perspectiva antiformalista, la previsión del artículo 29.2, en cuanto dispone: «La desestimación, por razones de forma, de un recurso de inconstitucionalidad contra una ley, disposición o acto con fuerza de ley no será obstáculo para que la misma ley, disposición o acto puedan ser objeto de una cuestión de ínconstitucionalidad con ocasión de su aplicación en otro proceso.»

Las «razones de forma» que han impedido llegar al fondo - y aquí puede caber desde 
actuación del Tribunal (parece lógico que determinados órganos institucionales de los que tienen acceso al Tribunal han de ser, por su propia especialización, sumamente cuidadosos en la observancia de los requisitos formales. Tal vez por eso necesitarían de un menor índice de previsiones para el saneamiento de actuaciones incorrectas. Pero con todo, insisto, no por esa situación de mayor familiaridad para con las exigencias procedimentales quedan desamparados para el supuesto en que las irregularidades se produzcan ${ }^{23}$.

Estudiada la situación legal, queda cubierta la primera etapa del camino, y ya se ha visto cuán halagüeño ha sido el resultado. Pero tal paso, con ser importante, no es suficiente. Ocasión ha habido en páginas anteriores de ver cómo normas y preceptos de excelente factura quedaban después desaprovechados - cuando no prácticamente negados- en el ruedo de las verdades de la actuación práctica. Es así como corresponde ahora pasar a la siguiente etapa para valorar la efectividad real de la ley en su todavía breve período de vigencia -y menor aún de funcionamiento del TC - . De entrada, adelantando valoraciones que luego se razonarán, se puede apuntar que desde los comienzos ha sido óptimo el impulso antiformalista que los doce jueces del Tribunal han sabido imprimir a su estela. Tal constatación, que se expresa muy sencillamente y sin apenas esfuerzo, es, sin embargo, de la mayor importancia y merece por eso ser resaltada a toda costa.

Paso así a continuación a ofrecer detalles de la jurisprudencia del Tribunal. He de advertir que he realizado sólo un muestreo. Personalmente soy decidido

el descuido en el plazo hasta la insuficiencia en cuanto a la legitimación (no cubrirse, por ejemplo, la cifra de los cincuenta diputados o senadores)-, si han tenido unas consecuencias rigurosas en una ocasión, no dejan ya para siempre imprejuzgada la eventual inconstitucionalidad de una norma. Incluso, aquí, habría que entender que si el impedimento de llegar al fondo - por esas razones de forma- se ha producido respecto a una cuestión de inconstitucionalidad - y véase lo que digo en la nota siguiente - no por ello quedaría cerrada la puerta para volver a plantear el mismo tema «con ocasión de su aplicación en otro procesors.

Es notable, y ya ha sido señalado, la similitud del 29.2, salvando las distancias, con el artículo $39.4 \mathrm{LJ}$, aunque con la introducción, que parece razonable, cuando quien va a enjuiciar es un único Tribunal, de la restricción a los solos supuestos en que el rechazo se haya producido «por razones de forma». Cabe recordar que esta matización no estaba en el Proyecto - art. 32.2 entonces- y que fue objetada en el Congreso por el Grupo Socialista, que, con su enmienda número 20 , pretendía que se circunscribiera la amplia facultad y se admitiera sólo «por razones de forma». Así lo aceptó la Ponencia en su Informe y desde allí ya pasó al texto definitivo.

${ }^{23}$ De especial consideración resulta el artículo 37.1 , referido a la «cuestión de inconstitucionalidad» (que pueden plantear, como es bien sabido, los jueces y tribunales). No hay en el entorno de este precepto referencias a la subsanación y la letra del artículo puede parecer un tanto dura en cuanto abre la puerta para que el Tribunal la rechace, en trámite de admisión, «cuando faltaren las condiciones procesales». Pero parece insólito el imaginar tan sólo que los órganos jurisdiccionales descuiden estos aspectos. Aun para el caso en que la incorrección surgiera no hay tampoco rigidez legal para la postura del TC. No aparece en la regulación el posible «deberá», sino que bien se ha cuidado el legislador de dejar la puerta abierta del «podrá».

Cierto que en el recurso de amparo - ya lo vimos- la regla es la de que intervengan especialistas en derecho como el abogado y el procurador. Pero sea por incultura jurídica o por lo que sea no han faltado los casos - luego tendremos oportunidad de comprobar algún ejemplo - en que un ciudadano se aventuraba a acudir solo ante el Tribunal, desconociendo exigencias que a los especialistas nos consta que son elementales. Sin duda, el recurso de amparo se presta más a ello. 
partidario de los estudios de series completas de jurisprudencia. Empero, la pretensión de aplicar aquí tal metodología hubiera implicado en mi caso un retraso que no me hubiera permitido alcanzar este número monográfico. Creo, de todas maneras, que la muestra es suficientemente representativa. Más aún: me he ceñido al estudio de las sentencias, lo que quiere decir que quedan fuera de consideración los autos, instrumento a cuyo través se proclaman, como regla, las inadmisibilidades. La lectura de los que he tenido oportunidad de conocer evidencia que abordaban supuestos palpables y gruesos en los que al Tribunal no le quedó más remedio que decretar el rechazo, por más que se hubieren tendido lazos y ayudas para evitarlo ${ }^{24}$. A mí me parece de sobra relevante fijarme en sentencias - que no escasean- en las que, a pesar de las insuficiencias formales, pudo llegarse al fondo del asunto. Aparte de que ya destaqué que el impulso antiformalista no emana sólo ante las inadmisibilidades, sino que puede detectarse a propósito de muy variados aspectos de la jurisprudencia. Pasaré así a señalar cuáles han sido los supuestos que se han beneficiado de esta corriente de interpretación. No obstante ello, me parece de interés detenerme con cierto detalle, para comenzar, en un caso específico convencionalmente elegido - sin ningún afán, por supuesto, de nada que se parezca a un comentario al mismo-, sin que entre tampoco a hacer valoración alguna del fondo de la cuestión que allí se discutía, por la sencilla razón - y no hay otras intenciones - de que me parece muy pedagógico al confluir en el mismo nada menos que cuatro causas de inadmisibilidad que han de ser sorteadas por el Tribunal, ya veremos en qué medida. A ello me aplico inmediatamente a continuación.

${ }^{24}$ En el Comentario que en BJC 3, pág. 220, se dedica a los autos dictados por el TC durante el año 1980 se indica lo siguiente: «El Tribunal Constitucional ha dictado 116 autos durante sus seis primeros meses de funcionamiento. Casi en su integridad los autos declaran inadmisibles recursos de amparo (...). En cuanto a razones de inadmisibilidad, destacan en número los autos que rechazan el recurso de amparo por no agotamiento de la vía judicial previa (...). Otros aspectos de admisibilidad destacable son: la legitimación para interponer el recurso de amparo (...); la exigencia de letrado en el procedimiento, en el que puede ser solicitada la actuación de un abogado de oficio (...); haber invocado en el proceso judicial previo el derecho constitucional invocado (...); no carecer el recurso manifiestamente de contenido que justifique una decisión por parte del TC...»

Pero en todos los casos, junto al dato de que la incorrección fuera grave, lo que debe ser resaltado, sobre todo, es que el recurrente, como norma, al menos cuando era posible, no utilizó la posibilidad de subsanación que en cada caso le fue brindada. Expresivo es así lo que se dice en el auto de 5 de noviembre de 1980 que se reproduce en el citado BJC 3. En efecto, el Fundamento Jurídico 1 afirma - y lo reproduzco como prototipo-: «El artículo 81.1 de la LOTC, incluido en el título VII entre las disposiciones comunes sobre procedimiento, exige que cualquier persona física o jurídica, para comparecer ante este Tribunal en alguno de los procesos constitucionales, deberá conferir su representación a un procurador y actuar bajo la dirección de letrado. El solicitante no alega su posible condición personal de licenciado en Derecho, única excepción reconocida por la ley respecto al precepto anterior $y$, por consiguiente, al no haber cumplido los citados requisitos inicial. mente, ni haberlos subsanado en el plazo que para ello se le otorgó, su demanda es inadmisible, a tenor de los artículos $81.1,85.2$ y $50.1 . b$ ) de la LOTC.»

De modo que está bien claro que la carencia inicial pudo haber sido subsanada. Para eso se le abrió un plazo ad boc. Bastante después de que hubiera transcurrido el plazo para interponer el recurso, por supuesto. Pero la oportunidad no fue aprovechada. Todo ello aparte de que el TC reconozca que no ha recibido competencia para amparar lo que el recurrente solicita: que se procese e inhabilite para toda acción y movimiento público sin la más ligera concesión de libertad al partido político conocido como Herri Batasuna y al Partido Comunista español. 
10. Se trata en concreto de un fallo bastante temprano, la sentencia de amparo de 11 de junio de 1981, de la que fue ponente el juez constitucional don Jerónimo Arozamena. Se enfrenta la sentencia con dos recursos acumulados por versar sobre materia similar: problemas de jubilados con la MUMPAL en relación con el cálculo de sus pensiones -el excluir en concreto las dos pagas extraordinarias del cómputo-. Pues bien: van a ser varias las causas de inadmisibilidad con que tendrá que enfrentarse el Tribunal (propuestas por el abogado del Estado ${ }^{25}$ o por la MUMPAL, siendo de advertir que el Ministerio Fiscal se manifestó proponiendo la estimación de los recursos). Se alegará así, primero -y numero yo libremente-, que el recurso se presentó fuera de plazo; del mismo modo, segundo, que «adolecen también los dos recursos del requisito de falta de representación procesal, pues al subsanar tal defecto formal había expirado ya el plazo legal para su interposición»; tercero, que «los recurrentes en ningún momento de los procesos judiciales han invocado los preceptos constitucionales vulnerados», y cuarto, que no se han agotado todos los recursos utilizables en la vía judicial previa.

A todas estas razones irá respondiendo el Tribunal Constitucional con las argumentaciones pertinentes, que rezuman a las claras la metodología de apertura y facilitación que practica.

A propósito de la objeción de fuera de plazo, tan automática si se quiere, recurso tan archiutilizado en otras instancias jurisdiccionales, el Tribunal va a decir lo siguiente con toda naturalidad:

«Por lo que se refiere a la otra alegación, esto es, a la del ejercicio tardío de la acción de amparo, estamos aquí en el caso de la transitoria segunda, uno, regla que, por referirse a los actos anteriores a la constitución del Tribunal, y además a un tiempo que comprende períodos de inhabilidad para las actuaciones judiciales, pudo inducir a interpretaciones distintas respecto al cómputo del plazo de los veinte días, y por ello el tratamiento del plazo en este comienzo del Tribunal se hizo desde las soluciones más favorables al enjuiciamiento de los actos presuntamente lesivos a los derechos o libertades...» $(\mathrm{FJ}, 6)$.

Sin insistir ahora sobre este punto, sobre el que luego volveré, me limitaré a destacar la afirmación, paradigmática sin duda, de que la interpretación «se hizo desde las soluciones más favorables al enjuiciamiento de los actos presuntamente lesivos». La fórmula, dentro de su sencillez, es espléndida. ¿Cuánto ha costado que llegaran a la prosa oficial con normalidad razonamientos de

${ }^{25}$ Con carácter general y muy aproximativo se puede constatar que lo normal sea que el abogado del Estado se acoja, con frecuencia, a los defectos procesales del solicitante de amparo, un poco a la manera de como ha venido haciendo en la jurisdicción contenciosoadministrativa, actuando más a modo de abogado de parte que al uso de lo que puede ser el Comisario del Gobierno ante el Consejo de Estado francés. En la sentencia de 14 de julio de 1981 se dejará constancia de cómo «... se sigue por el abogado del Estado un criterio estrictamente formalistas (FJ, 1). En cambio, en sentido muy diferente, al razonar el Tribunal, en la de 29 de marzo de 1982, a propósito de la inadmisibilidad que propone el abogado del Estado por falta de invocación formal del derecho constitucional, se dirá: «El abogado del Estado que suscita directamente esta cuestión entiende que hay que resolverla en sentido favorable a la admisibilidad del recurso (Antecedente $\left.\left.44^{\circ}\right)^{\circ}\right)(F J, 1)$. 
este tipo! Parece tan deseable y tan elemental una afirmación del género, que una vez normalizada será fácil que se olvide que hubo tiempos que alcanzar cotas tales era todo un poema. Quede, por tanto, resaltada. De otra parte, no le será difícil al lector relacionar esta prosa directamente con alguna postura doctrinal de la que antes me hacía eco.

No sé si alguna vez relatarán los primeros jueces constitucionales cómo se fraguaron internamente las decisiones orientadas a defender a toda costa, ya desde el inicio, el conocimiento del fondo, superando, por tanto, cualquier obstáculo de corte procesalista, si fueron conscientes o más bien casuales, si debieron vencer resistencias o surgieron con naturalidad, en qué se apoyaban tales decisiones o de qué pretendían apartarse. En suma, un sin fin de interrogantes que se le agolpan a cualquiera preocupado por el tema. Pero hasta que lleguen tales revelaciones, si es que llegan, lo que cuenta, el dato real y sobresaliente es que tales decisiones están ahí y desde el inicio han comenzado a ser operativas con enorme espectacularidad.

Se había alegado - segunda causa - la falta de representación procesal, pues cuando se subsanó este defecto ya había transcurrido el plazo -el plazo de veinte días, no muy amplio sin duda - para interponer el recurso. Ante esta objeción será contundente también el Tribunal:

«... ha de precisarse que el incumplimiento de lo que dispone el artículo 49.2.a es subsanable, sin que puedan traerse aquí interpretaciones que restrinjan el alcance sanatorio del artículo 85.2 para condicionar la justificación del requisito de postulación a que se haga en el plazo de interposición del recurso de amparo o al menos mediante poder otorgado antes de la demanda o dentro del plazo para el ejercicio de la acción de amparo. El artículo 85.2 de la LOTC permite la subsanación dentro del plazo que dice, y sólo en el caso de que no se haga en el mismo operará la causa de inadmisibilidad, regla que tuvo en cuenta esta Sala para admitir la demanda y darla curso tal y como dispone el artículo 51.1» (FJ, 6).

De este fragmento quiero destacar la frase «sin que puedan traerse aquí interpretaciones que restrinjan el alcance sanatorio del artículo 85.2». La afirmación y las consecuencias que de ella se derivan son notables. De un plumazo derrumbaba así el Tribunal Constitucional la tan consolidada doctrina - la tan discutible interpretación- que el Tribunal Supremo había puesto en práctica con harta generosidad y con la que se había horadado en gran medida el artículo 129 de la LJ. El intérprete puede pensar que la desalentadora experiencia sufrida por precepto tan esperanzador como el 129 de la LJ ha servido de acicate y revulsivo para que el Tribunal Constitucional reaccionara con toda energía a la primera oportunidad. No es ningún secreto que en la práctica los recursos suelen interponerse en las últimas fechas, en los últimos momentos aún (y dejo de lado corruptelas y apaños que a veces se utilizan o se han utilizado para presentar un recurso aun después de agotado el plazo). Si la de apurar el tiempo es, por tanto, la regla habitual en la práctica forense, de poco había de servir una oportunidad de saneamiento que permitiera rectificar sólo en cuanto se estuviera dentro de un plazo que, si no por definición, sí por praxis muy consolidada, lo normal es que esté agotado. 
Se alegaba también - tercero- incongruencia en la demanda. Y el Tribunal razonará:

«A primera vista pudiera decirse que las demandas no están presididas por la idea que respecto al petitum y a la causa de pedir luce en el artículo 49.1, por cuanto el acotamiento de los actos respecto de los cuales se pide amparo y el contenido de éste no son precisos y aun pudiera añadirse que, acudiendo a valoraciones literarias, resultan dificultosamente subsumibles en los requisitos que debe cumplir una demanda de amparo. Sin embargo, la demanda proporciona los datos indispensables para comprender lo que se pretende, lo que explica que el Tribunal, desechando tratamientos formales rigurosos, admitiera a trámite las demandas sin necesidad de abrir las posibilidades de subsanación que brinda el artículo 85.2 de la LOTC» (FJ, 5).

Tampoco ahora me distraeré en comentar doctrina tan explícita. Quede sólo constancia, para subrayar el notable valor que encierra, del talante con que el Tribunal se describe a sí mismo: «... el Tribunal, desechando tratamientos formales rigurosos...». Ni siquiera, por obvias razones de economía procesal, puesto que es posible «comprender lo que se pretende» - ¿en cuántas instancias habría que recordar razonamientos tan nítidos como éste?-, se entiende necesario acudir al trámite de subsanación, que, cuando menos, implica una pérdida de tiempo y de energía.

Habría una cuarta causa de inadmisibilidad: la de no haber agotado la vía judicial previa. Y ésta sí será aceptada. Tras un razonamiento detallado, afirma el Tribunal:

«El incumplimiento de lo que dispone el artículo 43.1 de la LOTC, como se ve, trasciende de lo formal, pues mediante el ejercicio del re. curso de apelación hubieran alcanzado los demandantes el reconocimiento de su derecho» (FJ, 2, in fine).

Es como si en medio de tantos intentos de salvación sintiera el Tribunal tener que dejar caer el recurso. Aunque, puesto que al final se va a reconocer esta causa de inadmisibilidad, alguien podría objetar que qué valor tienen todos los otros razonamientos que he destacado con anterioridad; denunciar, en definitiva, la finta de que en ocasiones hacen uso los jueces: sentar afirmaciones de gran entidad y aparato cuando para nada sirven a los fines del recurso concreto que va a ser rechazado. Pero no hay tal. No será preciso recordar que no estamos ante un auto de inadmisión, sino ante una sentencia que va a entrar a considerar gran parte de las argumentaciones utilizadas. Pero además hay en el fragmento de la sentencia recién reproducido una afirmación que merece destacarse: la de que el incumplimiento de lo dispuesto por el artículo 43.1 de la LOTC «trasciende de lo formal». Es como si se dejara constancia del deseo del Tribunal de minusvalorar lo accesorio y medial, siempre que esa labor de ayuda se supla por otros medios. Pero es que resulta, nada menos, que el agotamiento de la vía judicial hubiera obviado sin duda el recurso de amparo. En efecto, los recurrentes se aquietaron ante la sentencia de la Sala 
de lo Contencioso-Administrativo de la Audiencia de Albacete que les denegaba el recurso. La Sala de Valencia, en casos similares, mantendría, en cambio, el criterio contrario de favorecer a los recurrentes. Pero sobre todo el Tribunal Supremo llegaría a fallar favorablemente uno de los recursos -abordando el mismo problema-, declarando nulo el precepto reglamentario utilizado para llevar a cabo los cómputos de derechos pasivos cuestionados. Podemos volver de nuevo a la prosa de la sentencia del TC:

«Los recurrentes, como hemos dicho en el fundamento anterior, no han agotado los recursos utilizables dentro de la vía judicial, pues, pudiendo hacerlo, no han acudido al recurso de apelación. Junto a la significación que esto tiene desde la perspectiva del artículo 43.1 de la LOTC, adquiere una mayor relevancia, porque cabalmente está aquí, en la no utilización de la apelación ordinaria, la causa de que persista la contradicción entre las soluciones dadas a las pretensiones de los actores y las de quienes obtuvieron éxito ante otros Tribunales (...). $\mathrm{La}$ justiciabilidad de estos preceptos por la vía del recurso de apelación que se ha dicho hubiera conducido a una misma solución, pues lo que ha sentenciado el Tribunal Supremo en los recursos directos, con eficacia erga omnes y nulidad ab origine, coincidiría con la decisión judicial en los recursos indirectos....» (FJ, 2).

Es decir, hay un recordatorio implícito de que la labor de unificación de la jurisprudencia la debe realizar preferentemente el Tribunal Supremo. Encaja aquí la idea del carácter residual del amparo ante el TC, quien no debe ser entretenido con encomiendas que pueden ser resueltas con normalidad en otras instancias. El Tribunal Constitucional, al mismo tiempo que da aplicación a la normativa vigente, mantiene, al aceptar esta causa de inadmisibilidad, que no se trata de formalismos o requisitos más o menos superables, sino de algo tan elemental como de enmarcar sus propias actuaciones, de modo que no vaya más allá de donde le está encomendado. Fortaleciendo, en lo que al caso se refiere, la competencia del Tribunal Supremo -en clara postura de respeto para con éste-, llamado a funcionar de haberse interpuesto el recurso de apelación ${ }^{26}$. La sentencia, por esta y otras razones, denegará el amparo. Pero no

${ }^{26}$ ¿Cuándo se entiende que «se haya agotado la vía judicial procedente»? Acerca de esta cuestión, de peso, que la LOTC, como es obvio, no puede dar por resuelta en sus detalles, contiene afirmaciones de interés la sentencia glosada. He dudado si incluir estas reflexiones aquí o más adelante, en el texto, al enumerar las más destacables modalidades de actuación antiformalista del TC. En cualquiera de los dos lugares pueden encajar sin diferencia de significado. Ante tan equilibrada balanza aquí quedan, debiendo, sí, hacer hincapié en la línea interpretativa del TC.

El abogado del Estado sostenía una tesis peregrina a la par que peligrosa. Así se describe su postura al postular la inadmisibilidad: «Incumpliéndose además el requisito del agotamiento de la vía judicial procedente, a tenor del artículo 43 de la LOTC, al no haberse interpuesto el recurso de revisión» (Antecedente 5.'). Gravosa es, en efecto, la exigencia de un recurso que la LJ contempla sólo para supuestos excepcionales y que ella misma califica de extraordinario. ¿Qué pensar ante el hecho? Pues bien, el Tribunal Constitucional va a abordar la cuestión con solicitud, al tiempo que, de paso, nos regalará con alguna afirmación de interés. Conviene, así, reproducir el Fundamento Jurídico 1, muy completo, aunque resulte un poco largo: «Los actores han acudido a los procesos de amparo, que ahora han alcanzado el momento de sentencia, sin agotar los recursos utilizables 
es la cosa tan sencilla como pudiera parecer a simple vista: la propia sentencia reconoce que para entonces el Tribunal Supremo ya ha declarado nulos erga omnes y $a b$ origine ${ }^{27}$ —recuérdese el argumento recién transcrito- los preceptos reglamentarios en que se apoyaban los actos administrativos cuestionados por quienes pretendieron el amparo ${ }^{23}$. Hay una especie de doble juego.

dentro de la vía judicial, incumpliendo con ello el requisito que, en el caso del artículo 43 de la LOTC, manda su apartado 1 , y no porque se haya dejado de utilizar el remedio excepcional previsto en el artículo 102.1.b) de la LJ para el evento de sentencias contradictorias en casos que guardan la identidad que este precepto dice -remedio orientado a evitar soluciones opuestas, quebrantadoras de la unidad de doctrina jurisprudencial y dañosas para la justicia del fallo-, sino por no haber acudido al medio ordinario de la apelación, previsto, entre otros supuestos que no importan a los fines que enjuiciamos, en el artículo 94.2.b) de la ley antes dicha. $\mathrm{Y}$ es que la apelación ordinaria procede, con independencia de los criterios generales, definidores de la procedencia de la segunda instancia, en los casos del llamado recurso indirecto, contra disposiciones generales, esto es, el que se contempla en los párrafos 2 y 4 del artículo 39 de igual ley, dirigido a impugnar actos dictados en aplicación de una disposición general, fundado en que ésta no es conforme a derecho. De este modo el enjuiciamiento de los Reglamentos, no limitado, como es sabido, a la vía directa del recurso y tampoco al tratamiento por la vía de excepción de ilegalidad, se reconduce a la última decisión jurisdiccional del Tribunal Supremo, facilitando su invalidación general con ocásión de un acto aplicativo, que encontraría impedimentos si el Tribunal que enjuicia el Reglamento, como prius de su pronunciamiento respecto del acto aplicativo, no tuviera competencia para conocer de los recursos directos, y que se solvente, sin dificultad, cuando el tema puede llevarse hasta el Tribunal Supremo, en el que culmina la organización judicial.»

Como habrá podido comprobarse, se encierra en el largo párrafo doctrina de gran valía. Procurando no detenerme, no dejaré pasar la ocasión sin destacar cuatro puntos precisos:

a) Queda bien claro que, para considerar agotada la vía judicial procedente, no es preciso interponer el recurso de revisión.

b) Se recuerda algo tan obvio como es la posibilidad de recurso de apelación, en la vía contencioso-administrativa, que prevé, tras la reforma de 1973, el artículo 94.2.b) de la LJ, a propósito del proceso contra actos administrativos dictados a tenor de un reglamento de cuya juridicidad se duda. El Tribunal Constitucional no hace así sino dar virtualidad plena a la distinción, tan asimilada por la doctrina y la práctica, entre recurso directo y recurso indirecto contra reglamentos, así como a todas las consecuencias que derivan de la actual regulación legal.

c) A propósito del recurso indirecto va a abastecer un apoyo notable a la línea, aún débil, que va ya comenzando a dibujar la jurisprudencia contencioso-administrativa, siguiendo las incitaciones de la doctrina - y podrán recordarse, así, tomas de postura como la de García de Enterría o la de Embid Irujo-, de modo que al conocer de un recurso indirecto contra actos de aplicación se llegue a la declaración de nulidad del precepto reglamentario que les sirva de apoyo cuando se constate su antijuridicidad.

d) Destacaré, por último, la abierta línea de potenciamiento del Tribunal Supremo, órgano de unificación, aparte de en otros temas, en la delicada materia de las normas reglamentarias, cuya legalidad puede ser discutida por vía directa o por la indirecta.

${ }_{27} \mathrm{La}$ propia sentencia, en el Fundamento Jurídico 4 , reconoce, a propósito de las normas reglamentarias impugnadas, que «el acusado precepto ha perdido vigencia con efectos ex tunc, en la medida que no se hayan producido situaciones irreversibles».

${ }^{28}$ Hay en la sentencia una alusión clarísima a este tema, aun presentada bajo la capa de no querer entrar en el problema, cuando se afirma a propósito de los actores: "Que puedan favorecerse de la nulidad de la Orden ministerial (del art. 9.1) que por vía indirecta fue objeto de la pretensión de los precedentes procesos judiciales y el alcance de la revisión, en su caso, de los actos aplicativos cuya anulación no ha sido decretada, y los efectos temporales que corresponda a posibles rectificaciones del haber pasivo, para acomodarlas a la legalidad, no son temas que corresponda resolver a este Tribunal Constitucional y, desde luego, no son temas a resolver en estos procesos de amparo» ( $\mathrm{FJ}, 3$ ). 
Los recurrentes, por supuesto, pierden el recurso -y se les advierte amablemente, pero con advertencia de indudables visos de generalidad (es un aviso para todos) que no se debe entretenr al TC cuando en otra sede hubieran podido hallar amparo-, pero cuando prácticamente ya ha sido reconocida en otras instancias su pretensión. Las decisivas argumentaciones antiformalistas que antes he destacado no son sin más el homenaje generoso a quien va a perder su causa, aparte de que, aunque nunca estorben, no se ha erigido el TC para que distribuya cortesías tales. Bien venidas sean, pues: su fuerza y su viveza son tales que trascienden al caso y contribuyen a afianzar doctrina aparte de colaborar a la creación de un clima de que tan necesitados estábamos.

Reconozco el tanto de arbitrariedad, el convencionalismo que tiene el haberme detenido en un fallo como éste. Bien podía haber descrito otras sentencias de parejo alcance. Pero si lo importante era destacar unas interpretaciones, no ha resultado mal punto de partida esta sentencia sobre la MUMPAL.

De todas formas, en lo que sigue voy a variar el rumbo de mi exposición. En lugar de detenerme en los casos como tales pasaré revista, de forma bastante sumaria, pues si no se prolongarían estas páginas más de lo necesario, a aquellos puntos de inflexión en que sea más palpable el impulso antiformalista del Tribunal - ya han quedado enumerados en páginas anteriores al desarrollar el esquema de la regulación legal- - A propósito de cada uno de ellos ofreceré algún testimonio tomado de la jurisprudencia. De este modo paso a ocuparme seguidamente de los siguientes temas: plazo de interposición del recurso, agotamiento de la vía judicial procedente, legitimación, postulación, invocación del derecho constitucional violado, indicación por el Tribunal de motivos distintos a los alegados, incongruencia en el petitum $\mathrm{y}$, por último, prórroga de los plazos. 